\title{
Nitrogen Dynamics in the Olive Bearing Shoot
}

\author{
R. Fernández-Escobar, R. Moreno, and M.A. Sánchez-Zamora \\ Departamento de Agronomía, Universidad de Córdoba, Apartado 3048, 14080 \\ Córdoba, Spain
}

Additional index words. alternate bearing, crop load, Olea europaea, nitrogen fertilization, nitrogen partitioning, nitrogen storage, nitrogen mobilization

\begin{abstract}
Olive shoots were collected at monthly intervals during an off and an on year from nonirrigated, mature 'Picual' olive trees fertilized or nonfertilized with nitrogen. Young and mature leaves and stems and flowers and fruit developed during the on year were removed separately from the shoots to determine $\mathbf{N}$ concentration and $\mathbf{N}$ content per organ. $\mathrm{N}$ concentration decreased in young leaves and stems in spring and summer, and increased during the autumn in both off and on years. $\mathbf{N}$ concentration in old leaves and stems remained almost constant during the off year, and drops from April to October during the on year. The new tissues accumulated $\mathbf{N}$ during the off year and mobilized it during the on year to support growth. Leaves stored larger amounts of $\mathbf{N}$ than stems, and fruit developed during the on year became the main sink for $\mathrm{N}$ of the bearing shoot. Although the adjacent, mature leaves may have supported part of the $\mathbf{N}$ demand from the fruit, nitrogen must also have been mobilized from other storage organs to support fruit growth. No differences between fertilizer treatments were observed in the allocation pattern of $\mathrm{N}$, although $\mathrm{N}$ reserves increased in shoots of fertilized trees.
\end{abstract}

Nitrogen has long been considered the major nutritional factor in the growth and development of plants. Consequently, nitrogen is the mineral element most commonly used in the fertilization programs of horticultural crops. Considerable information is available on the uptake, storage, translocation and distribution of nitrogenous compounds in fruit trees and other woody plants (Kato, 1986; RoubelakisAngelakis and Kliewer, 1992; Titus and Kang, 1982). However, little is known about these processes in olive trees.

Woody plants store nitrogen in roots and in the bark of shoots and trunks (Titus and Kang, 1982). In deciduous trees leaves accumulate nitrogenous compounds during the growing season, and are mobilized into woody tissues before leaf fall. In evergreen trees such as citrus (Moreno and García-Martínez, 1984) and olive (Klein and Weinbaum, 1984), where leaves function for more than one year, nitrogenous compounds are also stored in leaves. Nitrogen reserves are translocated throughout the plant to support the new growth. It is well documented that growth of fruit trees early in the spring is supported by mobilization of nitrogen reserves from the storage organs (Kato, 1986; Titus and Kang, 1982; Weinbaum et al., 1984).

The study of the dynamic changes of nitrogen among the different tree parts, may be of interest for further studies on nitrogen nutrition in olive trees. However, it is very difficult to take the entire, mature tree for analysis in this kind of experiments, thus working with small units is necessary. Taking into account that olive leaves act as an important reservoir of nitrogen, studies may be focused on the olive bearing shoot, which is the fruiting structure in this species.

Received for publication26 Mar. 2003. Accepted for publication 29 Dec. 2003. This research was supported by CICYT Project AGF96-1116.
Olives flower on 1-year-old wood and display two inflorescences per node. Flower bud induction is manifested by July in the northern hemisphere (Fernández-Escobar et al., 1992). Floral differentiation is evident by March (Hartmann, 1951), and anthesis occurs by May. Shortly after anthesis, massive abscission of flowers and fruit occurs (Rallo and Fernández-Escobar, 1985). The remaining fruit usually persist on the tree until harvest, which takes place during the fall and winter. The olive tree exhibits a strong alternate bearing phenomenon. This phenomenon may affect nutrient content of the trees.

The objective of the present work was to characterize the dynamic changes of nitrogen in the olive bearing shoot, and to determine if these changes may be influenced by nitrogen fertilization or crop load.

\section{Materials and methods}

Nonirrigated, mature 'Picual' olive trees spaced $7 \times 7 \mathrm{~m}$ apart and growing in the Experimental Farm "La Mina" located at Cabra, Southern Córdoba province in Spain, were selected for the experiment. A randomized block design was used with two treatments and four blocks. Treatments consisted of the annual application of $0.5 \mathrm{~kg} \mathrm{~N} /$ tree and a nonfertilized control. Urea was the source of nitrogen, and was applied 50\% to the soil in March and 50\% on foliar sprays at a concentration of $4 \%$ in April, June, and September. The experimental unit was composed of four trees surrounded by guard trees.

Samples were collected in an off year, with average yields of $1.5 \mathrm{~kg} / \mathrm{tree}$, and in an on year, (average yield of $33 \mathrm{~kg} /$ tree). Two shoots per experimental tree, that is 32 shoots per treatment, were collected at monthly intervals during each year of the experiment. Shoots were taken at random around the tree at heights of
1.5 to $2.0 \mathrm{~m}$ above the ground. Once in the laboratory, young leaves and stems from the current-season's growth, mature leaves and stems formed during the previous season, and flower or fruit developed during the on year, were removed separately from each shoot, washed in deionized water, dried at $80^{\circ} \mathrm{C}$ for $48 \mathrm{~h}$, ground and stored in a oven at $60{ }^{\circ} \mathrm{C}$ until analysis. Nitrogen was determined by the Kjeldahl procedure.

\section{Results}

Leaf and stem $\mathrm{N}$ concentration was higher in younger leaves and stems in both off and on years and in both $\mathrm{N}$ treatments (Figs. 1 and 2). Nitrogen concentration of current-season leaves dropped during spring and summer and subsequently, during the autumn, these leaves showed an increase in $\mathrm{N}$ concentration. The drop in leaf $\mathrm{N}$ concentration could be due to dilution, since the current-season leaves increased in size during this period. On the contrary, the accumulation of nitrogen during the autumn may indicate storage of this element in the leaves. Nitrogen concentration of the previous season leaves showed a different pattern. During the off year, older leaf $\mathrm{N}$ concentration remained almost constant during the growing period, although a slight decrease was observed in nonfertilized trees. In the on year, on the contrary, nitrogen concentration dropped from April or May to October. Since no growth of old leaves is assumed to occur during this period, the results indicate nitrogen mobilization from the older leaves to support the new growth.

Seasonal changes of stem $\mathrm{N}$ concentration were similar to those observed in leaves. However, stem $\mathrm{N}$ concentrations were significantly lower than leaf $\mathrm{N}$ concentrations. Fruit $\mathrm{N}$ concentration dropped steeply from May to August, during the period of rapid fruit growth, and subsequently increased as observed in the other organs.

No differences were found in the pattern of $\mathrm{N}$ concentration changes between fertilization treatments. However, an increase in leaf and stem $\mathrm{N}$ concentration was found in fertilized trees, particularly during the on year. Nitrogen concentration of July samples of new leaves, when the critical values for olives were established, were above the threshold value for sufficiency of $1.5 \% \mathrm{~N}$ in all cases.

Nitrogen content per leaf of the previous season's growth remained almost constant during the growing period of the off year in both fertilization treatments (Figs. 3 and 4), although fertilized trees showed a slight increase in leaf $\mathrm{N}$ content. On the contrary, younger leaves accumulated large amounts of nitrogen during this period. During the on year, the rate of nitrogen accumulation in younger leaves was lower, and leaves accumulated lower amounts of nitrogen than in the off year, particularly when trees were fertilized with nitrogen (Fig. 4). Nitrogen was mobilized from older leaves during the on year, since $\mathrm{N}$ content in old leaves decreased in spring and summer. At the end of the growing period, $\mathrm{N}$ content per leaf was similar in young and old leaves.

Nitrogen content per stem increased during 


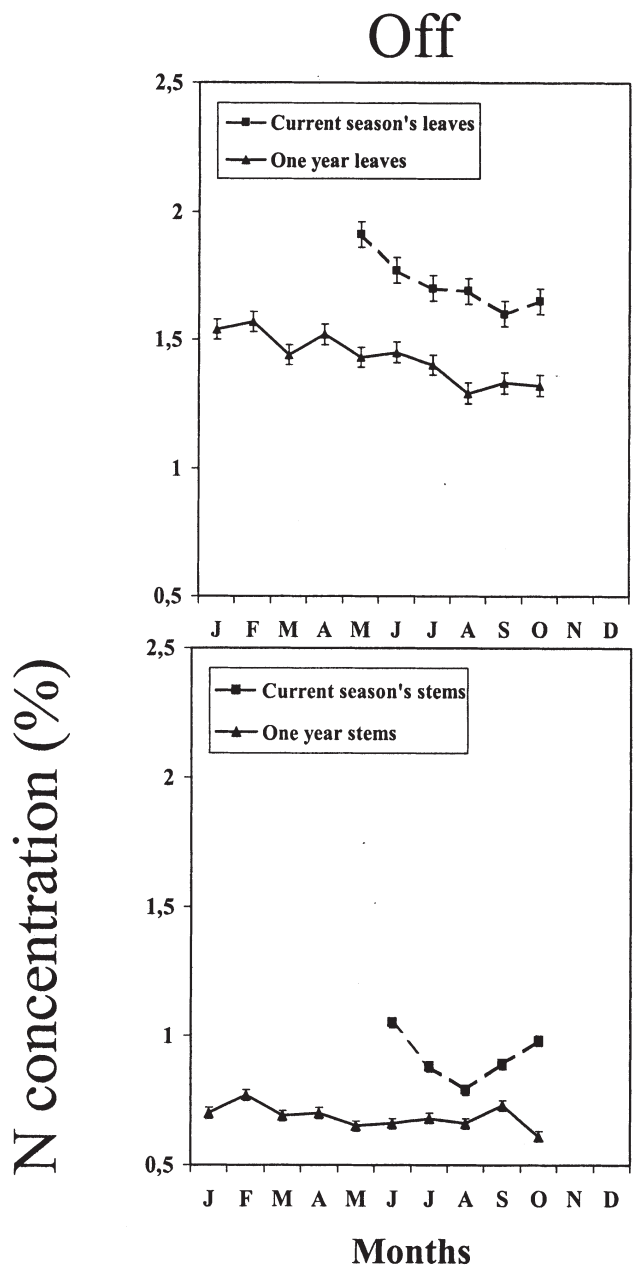

Fig. 1. Seasonal changes of $\mathrm{N}$ concentration in olive leaves, stems, and fruit developed during an off and an on year in non-N fertilized trees.

the off year in both fertilization treatments and in both young and old stems. Old stems showed two maximum peaks, in April and September, whereas younger stems accumulated nitrogen along the season. These results seems to indicate that nitrogen is mobilized from old stems during the spring growth, and it is subsequently stored in these parts during the summer. In the on year, $\mathrm{N}$ content per stem remained almost constant, showing a slight decrease after April in the older stems. Nitrogen content per fruit greatly increased during the season, beginning in June. During May and June, the time of anthesis, fruit set, and June drop, no $\mathrm{N}$ accumulation was observed.

Nitrogen partitioning into the different parts of the shoot is shown in Fig. 5. During the off year in both fertilized and nonfertilized trees, nitrogen was stored mainly in leaves and only in a small percentage, less than $10 \%$, in stems. At the beginning of the year, $90 \%$ of nitrogen was stored in old leaves. Beginning in April, when the new leaves were developing, the percentage of nitrogen decreased in old leaves and increased in the younger leaves. In July, when the spring flux of growth ceased, both kinds of leaves showed similar percentages of nitrogen accumulation, and remained approximately at the same values until the end of
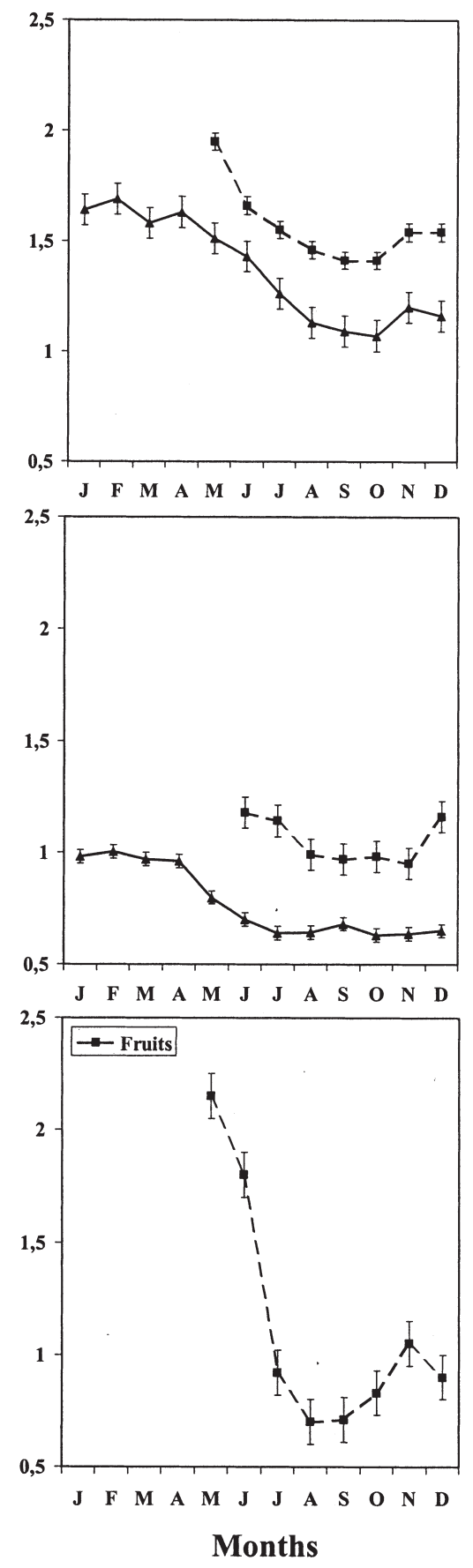

the growing period. In any case, total nitrogen in leaves represented $>90 \%$ of the total shoot content. The percentage of nitrogen in stems slightly decreased along the season.

During the on year, when the fruit were present, the dynamic changes in nitrogen were altered. Most of the nitrogen, $>60 \%$, was accumulated in fruit at the end of the year and was removed by the crop, indicating that the fruit is the most powerful sink for nitrogen of the bearing shoot. Young leaves stored smaller amounts of nitrogen in the on year than during the off year, and the nitrogen stored in old leaves drastically decreased along the growing season. At the end of the period, both kinds of leaves stored similar percentages of nitrogen, between $10 \%$ to $20 \%$. Small changes were observed in 
Off

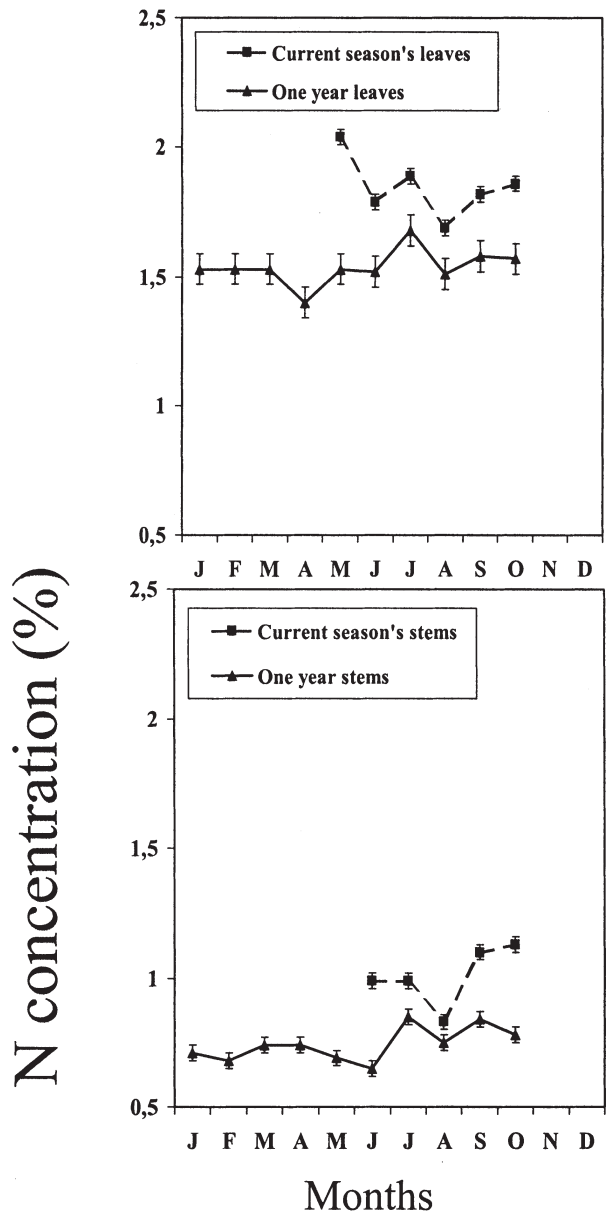

Fig. 2. Seasonal changes of $\mathrm{N}$ concentration in olive leaves, stems, and fruit developed during an off and an on year in $\mathrm{N}$ fertilized trees.

stems, which stored lower amounts of nitrogen. No differences between fertilization treatments were noted in the nitrogen allocation pattern in both off and on years.

\section{Discussion}

Crop load may influence tree performance in the subsequent year and, particularly, may affect tree nutrient content. However little attention has been paid to the impact of alternate bearing on tree mineral nutrient content and allocation patterns, although the phenomenon is common among fruit tree species (Monselise and Goldschmidt, 1982). In pistachio, a severely alternate-bearing deciduous fruit tree species, a greater nitrogen accumulation in perennial parts of the trees was observed during the off year (Brown et al., 1995; Weinbaum et al., 1994). There is also a greater nitrogen demand during the on year (Picchioni et al., 1997).

For olive trees we have obtained similar results. Nitrogen was stored in new leaves and stems, and also in old stems, during the off year, and appeared to be mobilized from these tissues during the on year to support new growth (Figs. 3 and 4). These results are consistent with those reported previously
On
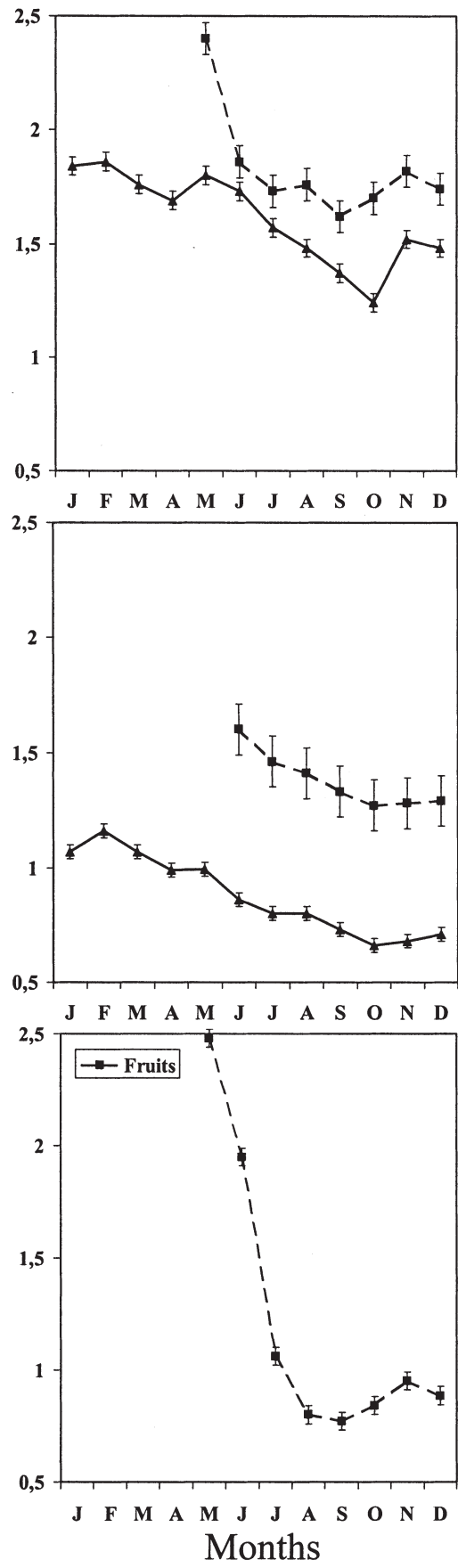

in olive leaves during an alternate-bearing cycle (Fernández-Escobar et al., 1999). Little accumulation in the new tissues was observed during the on year, with the exception of fruit that represented the main sink for nitrogen for the bearing shoot. This nitrogen was obviously removed by the crop and not reabsorbed by the tree, and affected both the nitrogen content of the tree and nitrogen cycle in the orchard.

Little nitrogen mobilization from the shoot seemed to occur during the off year. A decrease in nitrogen content during the spring was observed only in old stems, but this small amount of nitrogen may not have been enough to support vegetative growth. We hypothesize that vegetative growth is supported by nitrogen stored in other tree parts, 2-year-old leaves, the 
Off
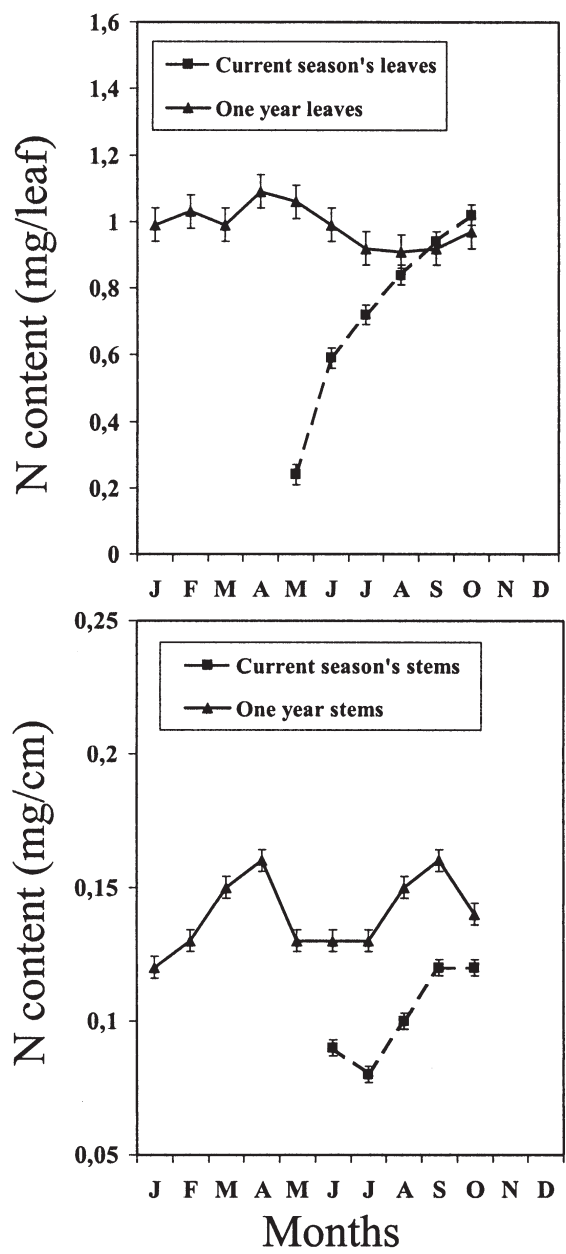

Fig. 3. Seasonal changes of $\mathrm{N}$ content in olive leaves, stems and fruit developed during an off and an on year in non- $\mathrm{N}$ fertilized trees.

bark of trunks and main branches, and roots, at least during the greater vegetative growth of the off years. Nitrogen stored during the off year in new leaves is mobilized during the subsequent on year. According to our results, during the on year $\approx 0.16 \mathrm{mg} \mathrm{N} /$ leaf was mobilized from March to June, representing the period of greater vegetative growth, and $\approx 0.29 \mathrm{mg}$ N/leaf from June to September, when decrease in nitrogen content per leaf ceased. Fruit accumulated $\approx 7 \mathrm{mg} /$ fruit from June to September, so each fruit may need $\approx 24$ mature leaves to support its $\mathrm{N}$ demand during this period. This number of leaves per fruit is very high for an on year. When olives bear a high yield, there are two inflorescences per two-leaf node and after June drop, 'Picual' trees retain at harvest $\approx 50 \%$ of inflorescences with an average of one fruit per inflorescence (Rallo and FernándezEscobar, 1985). This means that there are two mature leaves per fruit. Therefore, nitrogen must also be mobilized from other reservoirs to support fruit growth. However, leaves may contribute enough $\mathrm{N}$ to satisfy $\mathrm{N}$ demand by the fruit in the early stages of fruit development. In accordance with this hypothesis, we can establish that $\mathrm{N}$ stored in leaves during the
On
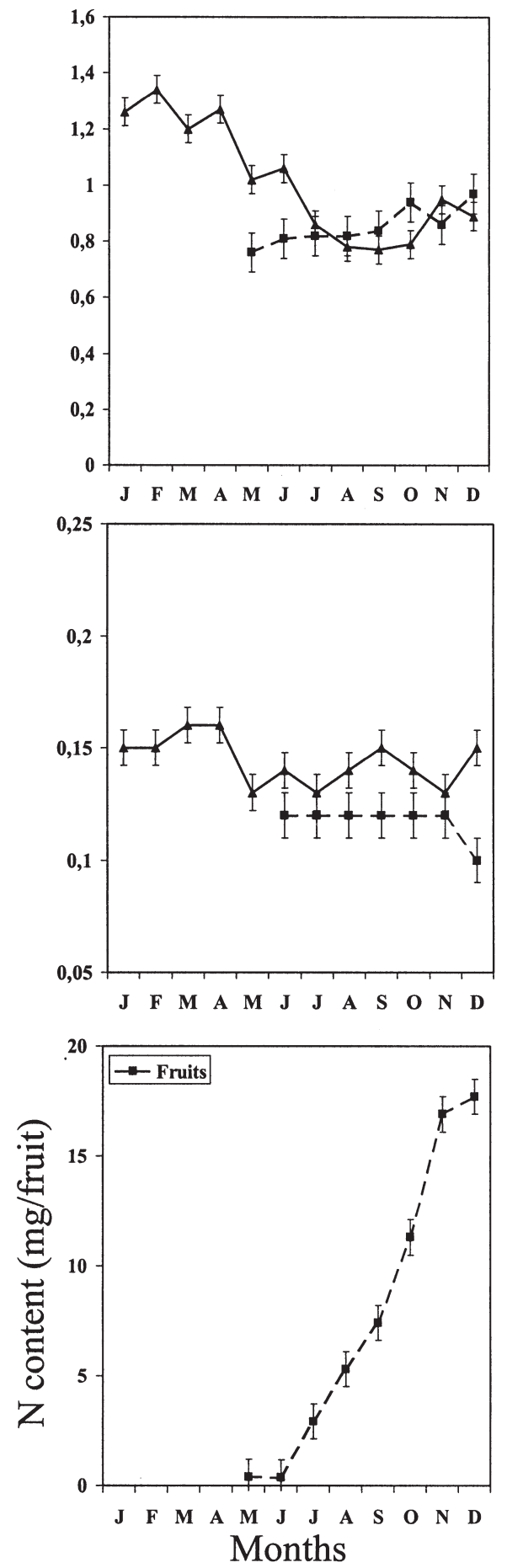

off year is mobilized at the beginning of the spring of the next on year to support the new shoot growth, and subsequently during late spring and summer to partially support fruit $\mathrm{N}$ demand. From September to December fruit accumulate $>7 \mathrm{mg} \mathrm{N}$, but this nitrogen does not seem to be mobilized from leaves.

Nitrogen partitioning among the different parts of the bearing shoot was in consequence affected by crop load. During the off year, shoots stored $\approx 90 \%$ of nitrogen in the leaves and $<10 \%$ in stems, whereas in the on year they stored only $30 \%$ to $40 \%$ of nitrogen in the leaves and $<5 \%$ in stems. The remaining $60 \%$ 
Off
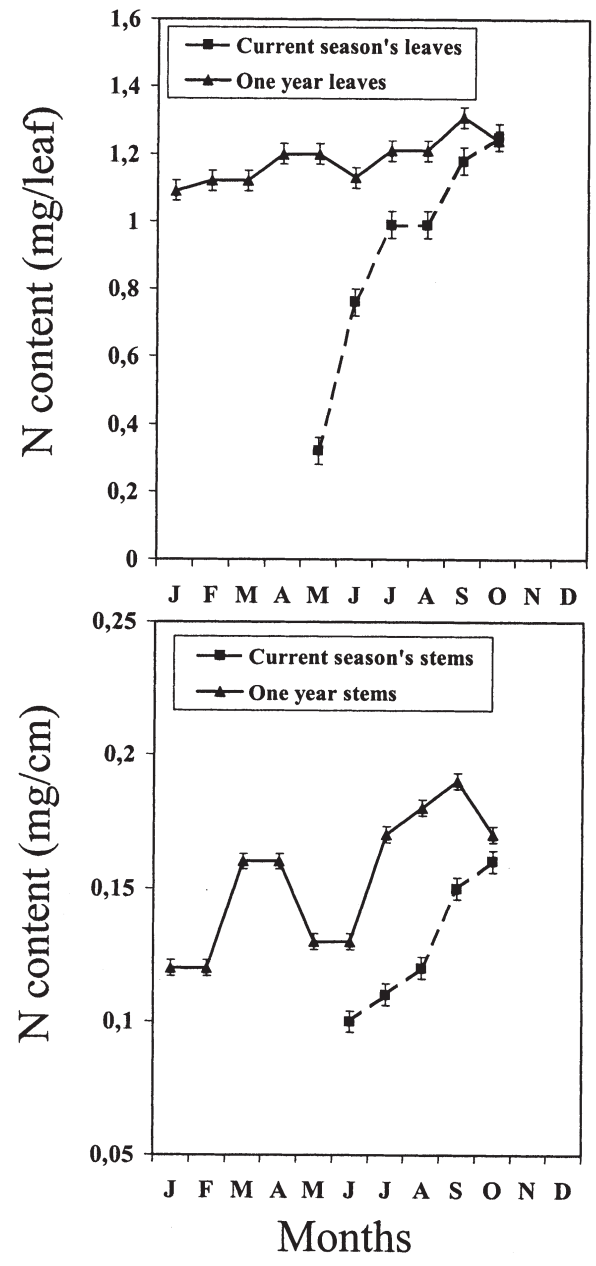

Fig. 4. Seasonal changes of $\mathrm{N}$ content in olive leaves, stems, and fruit developed during an off and an on year in $\mathrm{N}$ fertilized trees.

to $70 \%$ of nitrogen was accumulated in fruit. Thus trees entering their on year have greater nitrogen reserves than trees entering their off year, as observed by Weinbaum et al (1994) in pistachio.

It has been reported that olive leaves constitute a major reserve of carbohydrates (Priestley, 1977) and nitrogen (Klein and Weinbaum, 1984), as occurs in other evergreen trees such as Citrus (Kato, 1986). Using labeled N, Klein and Weinbaum (1984) found that only a small proportion of the labeled $\mathrm{N}$ applied to olive leaves moved into the developing organs, even when $\mathrm{N}$ was applied in the spring. Accordingly, growth of olive trees seems to be supported mainly by the mobilization of nitrogen reserves from the storage organs, as has also been reported for other fruit tree species (Kato, 1986; Titus and Kang, 1982). This can explain why applying $\mathbf{N}$ fertilizer to nitrogen sufficient olive trees resulted in an increase in $\mathrm{N}$ reserves in the bearing shoot (Figs. 1 to 4), but did not affect the nitrogen allocation pattern. These results suggest that most of the nitrogen mobilized to support new growth came from the nitrogen stored in old tissues, and not from the actual application of fertilizers.
$\mathrm{On}$
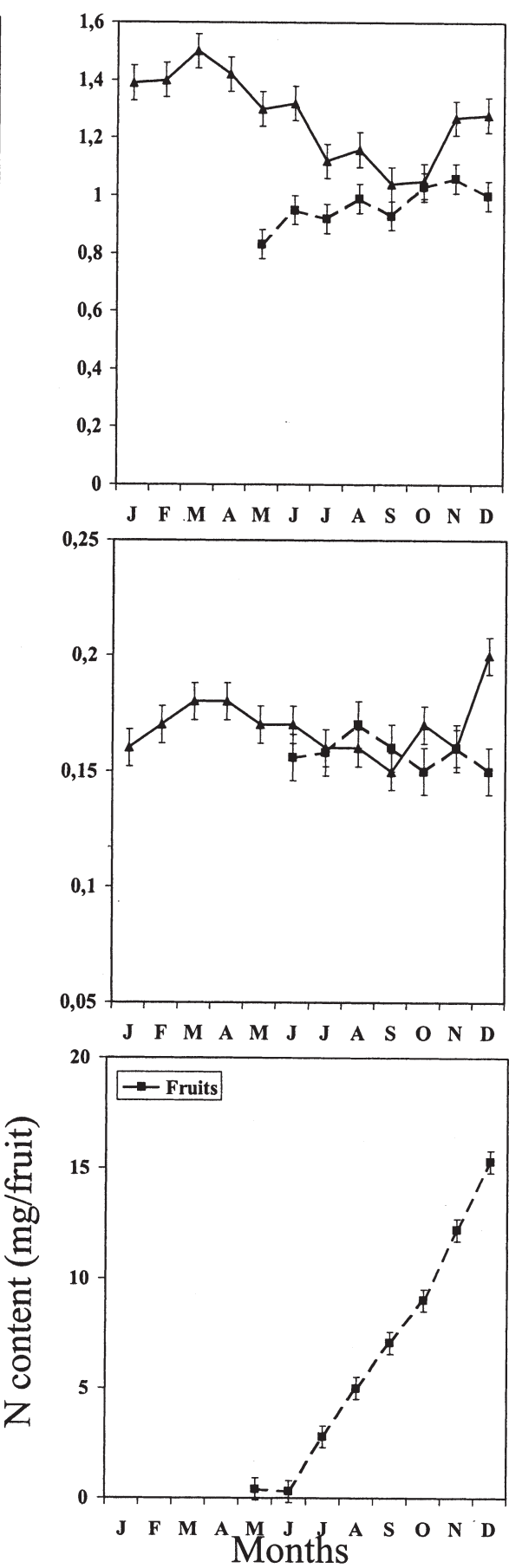

In summary, we can conclude that alternate bearing clearly influences the nitrogen dynamics of the olive bearing shoot. Leaf and stem age also play an important role in this process since the new leaves and stems store nitrogen during the off year, and mobilize it during the subsequent on year to support new growth. However, leaf and stem nitrogen content does not seem to be enough to satisfy the $\mathrm{N}$ demand of the tree, so nitrogen must also be mobilized from other reservoirs to support growth. Fruit represent the main nitrogen sink in the bearing shoot, and may be partially dependent on nitrogen stored in adjacent, mature leaves until September, when fruit accumulate $<50 \%$ of the 

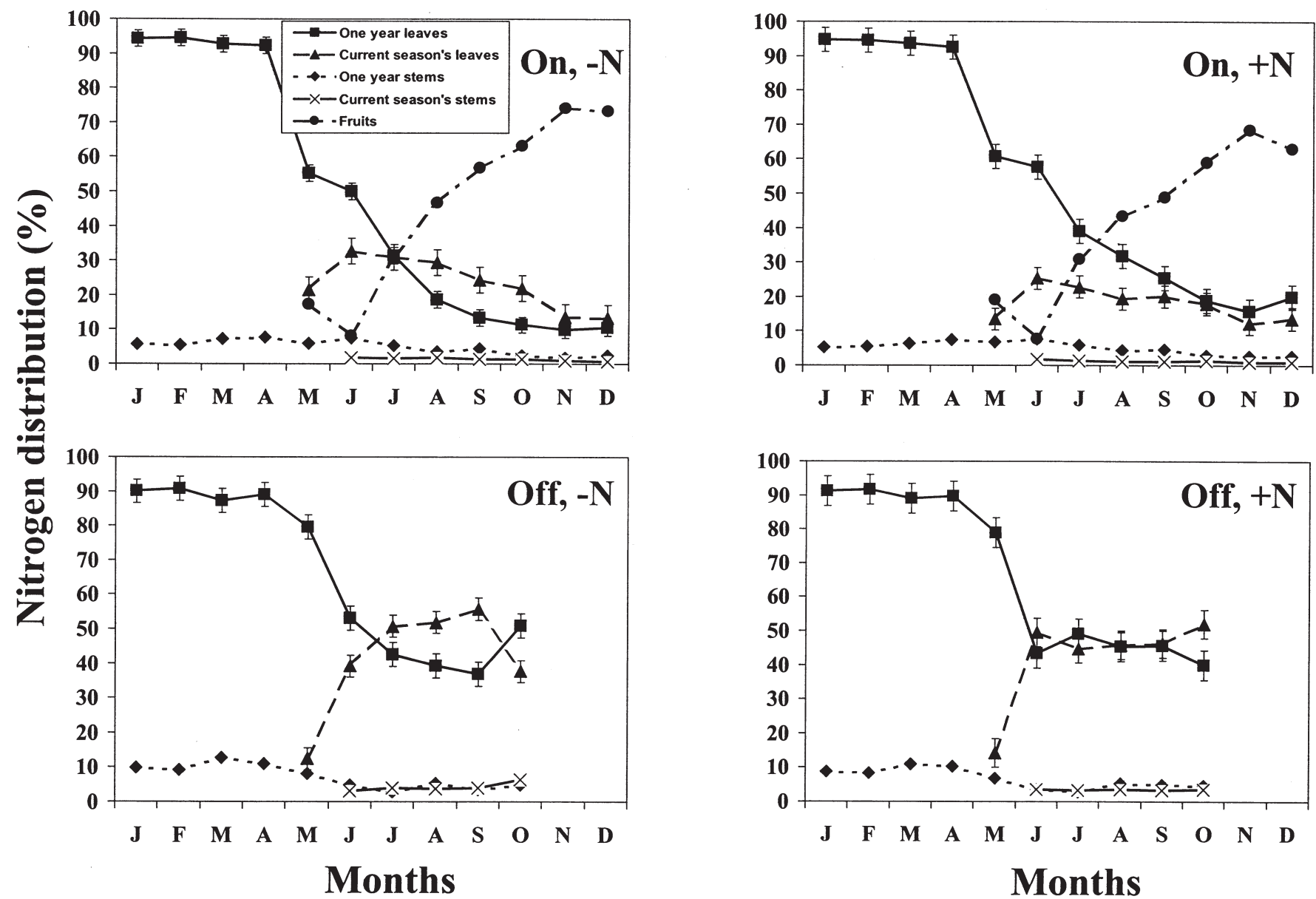

Fig. 5. N partitioning in the olive bearing shoot during an off and an on year in both $\mathrm{N}$-fertilized and nonfertilized trees.

total nitrogen removed. Applying $\mathbf{N}$ fertilizer to nitrogen sufficient trees did not affect the nitrogen allocation pattern, although it did increase nitrogen reserves in the bearing shoot.

\section{Literature Cited}

Brown, P.H., S.A. Weinbaum, and G.A. Picchioni. 1995. Alternate bearing influences annual nutrient consumption and the total nutrient content of mature pistachio trees. Trees 9:158-164.

Fernández-Escobar, R., M. Benlloch, C. Navarro, and G.C. Martin. 1992. The time of floral induction in the olive. J. Amer. Soc. Hort. Sci. 117:304-307.

Fernández-Escobar, R., R. Moreno, and M. GarcíaCreus. 1999. Seasonal changes of mineral nutrients in olive leaves during the alternate-bearing cycle. Scientia Hort. 82:25-45.

Hartmann, H.T. 1951. Time of floral differentiation of the olive in California. Bot. Gaz. 112:323-327.
Kato, T. 1986. Nitrogen metabolism and utilization in Citrus. Hort. Rev. 8:181-216.

Klein, I. and S.A. Weinbaum. 1984. Foliar application of urea to olive: Translocation of urea nitrogen as influenced by sink demand and nitrogen deficiency. J. Amer. Soc. Hort. Sci. 109:356-360.

Monselise, S.P. and E.E. Goldschmidt. 1982 Alternate bearing in fruit trees. Hort. Rev 4:128-173.

Moreno, J. and J.L. García-Martínez. 1984. Nitrogen accumulation and mobilization in Citrus leaves throughout the annual cycle. Physiol. Plant. 61:429-434.

Picchioni, G.A., P.H. Brown, S.A. Weinbaum, and T.T. Muraoka. 1977. Macronutrient allocation to leaves and fruit of mature, alternate-bearing pistachio trees: Magnitude and seasonal patterns at the whole-canopy level. J. Amer. Soc. Hort. Sci. 122:267-274.

Priestley, C.A. 1977. The annual turnover of resources in young olive trees. J. Hort. Sci. 52:105-112.

Rallo, L. and R. Fernández-Escobar. 1985. Influ- ence of cultivar and flower thinning within the inflorescence on competition among olive fruit. J. Amer. Soc. Hort. Sci. 110:303-308.

Roubelakis-Angelakis, K.A. and W.M. Kliewer. 1992. Nitrogen metabolism in grapevine. Hort. Rev. 14:407-452.

Titus, J.S. and S.M. Kang. 1982. Nitrogen metabolism, translocation, and recycling in apple trees. Hort. Rev. 4:204-246.

Weinbaum, S.A., G.A. Picchioni, T.T. Muraoka, L. Ferguson, and P.H. Brown. 1994. Fertilizer nitrogen and boron uptake, storage, and allocation vary during the alternate-bearing cycle in pistachio trees. J. Amer. Soc. Hort. Sci. 119:24-31.

Weinbaum, S.A., I. Klein, F.E. Broadbent, W.C. Micke, and T.T. Muraoka. 1984. Effects of time of nitrogen application and soil texture on the availability of isotopically labeled fertilizer nitrogen to reproductive and vegetative growth of mature almond trees. J. Amer. Soc. Hort. Sci. 109:339-343. 